\title{
Study on Social Problems and Social Policies of the Chinese resource-exhausted cities
}

\author{
Ge Shaolin ${ }^{1^{*}}$ \\ Public Management, \\ Yunnan University of Economics and Finance, \\ Kunming, P.R.China, 650221) \\ geshaolin72@163.com \\ Han Quanfang ${ }^{2}$ \\ Public Management, \\ Yunnan University of Economics and Finance, \\ Kunming, P.R.China, 650221) \\ hqfang666@163.com
}

\author{
$\mathrm{Xu}$ Weiwei ${ }^{3}$ \\ Public Management, \\ Yunnan University of Economics and Finance, \\ Kunming, P.R.China, 650221) \\ 649205029@qq.com
}

Wang $\mathrm{Xin}^{4}$

Public Management,

Yunnan University of Economics and Finance,

Kunming, P.R.China, 650221)

2532085670@qq.com

\begin{abstract}
Social conflict follows beginning and ends of social change of the resource-exhausted cities. Social policies are urgently needs action in many of the resource-based cities in China, especially the resource-exhausted cities. Many resourceexhausted cities of China are commonly faced with a range of issues of ecological environment deterioration, a serious problem of employment opportunities, notable contradictions between mine and countryside, the alienation of mining classes, the lagging of the social construction. Based on the analyze of social policies from the social theoretical perspectives, which presents a pattern of the construction of social policies in the resource-based cities.
\end{abstract}

Keywords-Resource-exhausted cities ; Social Problems ; Social policies; Community Conflict

\section{INTRODUCTION}

The problems of the resource-based cities are the outstanding issues of have experienced or are experiencing. Effective social policies could solved or at least completely the resource-exhausted cities' issues. In 2008, 2009, 2011, China has set 69 -city of resource-exhausted, $58.5 \%$ of the total number of the cities in our country. Its operation covers 23 provinces (autonomous regions) of China. [1] At the moment, these cities are commonly faced with a serious problem of "the plight of mineral depletion" and city decline, and a single industry structure, ecological environment deterioration, prominent contradictions and prone, the lagging of the social construction. Social conflicts follow social change of the resource-exhausted cities, and make the mine into "a risk society" (Urlich Beck, 1992). [2] But the main function of "social policies" (Wagner, 1837) are deal with the social risks, promote social redistribution and achieve the goals of social integration. The social policies of the mining area is are urgently needs action in many of the resource-based cities in China, especially the resource-exhausted cities. The study of the social problems and social policies of the mine are the key to building a harmonious society of the mine.

\section{The Social Problems in Resource-exhausted Cities}

\section{A. Ecological environment deterioration}

Mining activities has farther aggravate geologic hazardprone and the worsening ecological environment in mining area, the problem of poverty in mining area is getting more and more conspicuous. Nearly 200 years in mining area of Dongchuan in China, along with continuous expansion of copper mining, moving from "the traditional of copperextraction chopping down trees and using wood as fuel to break stone" after the founding of the People's Republic nearly 50 years of continuous mining. Excessive exploitation factitious could spell devastating ecological disaster is weakest area in ecological environment of whole the upper reaches of Changjiang River. According to the statistics, there are 107 debris flows gullies in Xiaojiang valley development of the Dongchuan side alone. Among them, 25 debris flows gullies are dangerous. Big debris flow flare up 15 times annually on average.[3]

\section{B. A serious problem of employment opportunities}

Conflicts resulting from laid-off workers are the biggest problem to face the community of the resourcebased city. Unemployment problem include such traits as an unemployment epidemic, young unemployed person is in the majority, re-employment difficulty, and so on. In 2000, after bankruptcy proclaim from Dongchuan Copper Mines Administration in Yunnan, China. All of 11179 employees have 5425 workers got one-time find a place for the cost, but there are 4255 workers were unemployed. And they make the personnel of unemployment had increased steeply. Because of 
social problem of Pension, Medicare and Employment of more than 17000 workers' families in the original Mining Bureau, the social problem has become the biggest social problem . In 2003, the unemployment of the Dongchuan area had raise to more than 9366 people. As the same time, registered urban unemployment rate reached 40.2 percent, it is the most in the country. Poverty is the bottleneck of the development of resource-scarce cities. A large number of the unemployed being unable to locate a job for a long times, and it necessary to cause high unemployment coexist with high "minimum".

\section{Notable contradictions between mine and countryside}

Notable contradictions between mine and countryside is mine production activities touch farmers and the farmers' interest, it caused mining enterprises to the conflict and relationship between local government and local peasants by tension. The truth of notable contradictions between mine and countryside is the performance of the unbalanced interest coordination between the various communities. The factor of land occupation, damaged house, farmland collapse, soil erosion, tombs collapse, exhaustion of water resources and environmental pollution are the major factors of notable contradictions between mine and countryside. Notable contradictions between mine and countryside not just a higher frequencies of occurrence, but the factors of local mass disturbances, jumps the ranks appeals for help and the case of social security are the most important factors.

\section{The alienation of mining classes}

The alienation of mining classes forms from all walks of life and included mine owners, miners, mine families and mine farmers. The interest consciousness of different social groups and classes are constantly arouses and enhances. The disintegration of interest was bound to produce a wide range of contradiction and conflict, and it could lead to driven differences in wealth. In the distribution of benefits from mineral resource exploitation, has established the irrational distribution model situation of profit of "the tax revenue is the country, the benefit is the boss, the damage is local villagers". Local farmers cannot share the results of resource development but they have to suffer the damage caused by resource development. It has provide a dynamic counterpoint between the destroy interest of the villagers and the boss rich of mining industry, and it makes in mentally is extremely uneven. The result of the alienation of mining classes is the concentration of mine power, concentration expression is mean that "mine manager is the mayor, next is local government and the mine elite" . Under market economic system, the mining area related to the complex relationship among mining enterprises, local government and the people of the mining area, and the conflict of the mining area is deteriorating and escalating.

\section{E. The construction of community}

The resource-exhausted cities construction of community are generally face with a series problem of social cohesion and a sense of belonging is weaker, and social organization is unsound. The organization differentiation of the mining area show that the mine organization of production, life service and culture separate from mining enterprises, and it add the organization of local mineral development and Wade mine family. In the construction of the mining city communities, the phenomenon of lack for "inverse non-unitized" and

"community memory" are especially prominent. The mining city has become a city of loss the "unit", but it cannot have a community and go back to being the individual of lonely and atomism. The mining area features a special historical and complexity, it will face more difficulties in the construction of the mining city communities, and the limitation of national totalitarianism is fully reflect in the construction of the mining communities.

\section{Social CONFLict AND SOCIAL Policy OF RESOURCES EXHAUSTED CitIES}

\section{A. Power conflict}

Marx (Karl Marx, 1867) believed that society is full of conflicts and the unequal allocation of scarce resources, he regarded the conflict as a common phenomenon in modern society and a key to explain human history. Webb (Max Weber, 1922) thought that the fundamental reason of the conflict is highly related to power, wealth and prestige, fracture of the return distribution, low social mobility rates. Mills (C. Wright Mills, 1956) proposed a "power elite" and "mass society" of the conflict, the internal conflict of power structure. Dahrendorf thought social conflict origins from competing for scarce resources, such as power and authority and so on. The social conflict is completely structural. He also put social vicissitudes as the change of authority structure (Dahrendorf 1957). Coser (Lewis Alfred Coser, 1956) deemed that the root of the conflict is multivariate, power, status and resource allocation and value concept can become a conflict based. The main manifestation of social conflict is enhancement of legitimacy crisis and lower sense of injustice. Saunders pointed out that any conflict in a community includes the following 3 elements: the opposite relationship, different power distribution and some intense emotions of community residents. Mineral resources are nonrenewable resources, and is a kind of scarce resources that obtain the enormous benefits, and the possession of the mineral resources mining rights and enjoy into interest groups must be have mine power mine elite ", such as the owner of the mine, the village cadres, foreign investors and state-owned mining enterprises cadres.

\section{B. System conflict}

Since the reform and opening up Chinese, structural transfer and synchronized reform in social transformation, which touch and collision people's benefit, power relations and values, increase the possibility of social conflict. Deepen the reform in the allocation of social resources and the pattern of interests produced by change of every hue of the interest groups, the conflict between the perplexing. With the further differentiation of social stratum, the dominant group in the society often affect the distribution pattern of social interests, which leads to more social conflict. Different levels of social structure in china, such as the city and countryside, the new rich class and the new bottom of society, developed areas and underdeveloped areas, within and outside the system and so on, 
appear various "fracture". In real life, especially the social life level in the low development stage, the main social contradiction is the interest contradiction, the material interests of the difference is the cause of all kinds of social conflicts. The people of "get rich quick" and "rapid poverty, both think conflict between now and the future class will become more serious. Such as state-owned mining enterprises by the system reform caused laid-off workers of group conflict.

\section{Interest conflict}

The main function of social policy is deal with social risks, promote social redistribution and social integration. Western mining area mostly at mountainous area and the national minority is concentrated, is connected to the city, town and country, the intermediate zone, the mining area has different economic organizations and interest groups, these interest groups between the whole level of interest and profit ability have bigger difference, the triggered a conflict of interest between different interest groups. Social policy of mining area is a policy tool that can adjust and improve the interest relationship between mining enterprises, the village committee and mining area farmers. At present, the interests of farmers and rural area were damaged seriously, mines are increasingly prominent contradiction, in the face of mining area farmer social policy problem is very serious, the support of social policy operation system has not been established. To build shared mechanism and contradiction coordination mechanism of the government as the leading factor, damaged by the mineral resources development benefit from the direction of the benefit party for compensation of is insurance against mining social order confusion or "solution of the social group, is the key to achieve the results of the development of mineral resources sharing and mining social sustainable development. With the structural adjustment and innovation of the institutional change, brings the contradictions and conflicts between different interest groups can be attributed to the structural strain".

\section{The Construction of Social Policy OF RESOURCE EXHAUSTED CITY}

The goal of the construction of social policies is the Sustainable development in the resource-based cities. In 1987, the World Commission on Environment and Development ( WCED ) has published a report Our Shared Future, this report officially uses the conception of Sustainable development. The thesis systematically explains the Sustainable development and produced a wide-ranging implications. The Sustainable development is defined as "development which meets the needs and aspirations of the present without compromising the ability of future generations to meet their own needs in Our Shared Future. It includes two basic concepts: the conception of needs, especially the basic needs of the peoples in the world, and think of it put in the position of special priority; the conception of limit, technology status and social organization impose limitations on the environment to meet the ability of present and future needs. "The Sustainable development is an inseparable system, it not only achieving economic development purposes, but also protect the natural resource and the environment that people depend on, include atmosphere, freshwater, ocean, land and forests. It makes sustainable development and a happy and peaceful life for future generations. The Sustainable development and environmental protection are ties and not equal. Environmental protection is an important aspect of the Sustainable development. The core of the Sustainable development is development, but it means that pursue economic and social development under the premise of strict population control, improve population quality and environmental protection, sustainable utilization of resources. Development is the prerequisite of the Sustainable development; Man is the powerhouse of the Sustainable development; The Sustainable development is the real development, it makes sustainable development and a happy and peaceful life for future generations.

The Sustainable development of the resource-based cities is of great significance to maintenance the security of energy, move the new style industrialization and urbanization, promoting social harmony, stability and national solidarity, building a resource-conserving and environment-friendly society. The Sustainable development of the resource-based cities should take comprehensive treatment for the region ecological environment. According to the principle of "who governance, who benefits", so that guide all kind of market join in the comprehensive treatment of the region ecological environment, and accelerating pollution rectification and ecological restoration engineering. The improvement of human residential environment of the resource-based cities, the resource-based cities put ecological construction and environmental protection input into the important of the public finance expenditures. According to the sustainable development theory, scientific and strict implementation of the urban and rural planning, reinforce infrastructure constructions, strengthen and improve the urban functions, create occupies the environment suitably. Enhancing the protection of the mine eco-environment, planning the exploration of the mine resources in a scientific way, try to prevent environmental pollution and ecosystem destruction. The governance of the " three wastes " of the mine and geological disasters at the same time. Prevent land desertification, soil erosion and water damage.

The compensation mechanism of resource development of resource exhausted city is the core of construction of social policy of the mining area and the specific form. Compensation for resource exploitation is a restoration to influenced environment conducted by main developers and other mineral resource beneficiaries who made short-term or long-term negative effects to local residents' daily life and production by environmental destruction when running natural resource development activities. It provides others residents as well as organization with assistance in substance or financial condition, which helps promise that at least there is no quality decrease to the influenced objects' production and daily life. From the subject of compensation, compensation for resource exploitation involves the compensation for ecological, individual residents and villagers affected by the process of resource development; from the contents of the compensation, compensation for resource exploitation includes damage compensation, compensation for the occupation, opportunity compensation and benefit compensation; from the form of 
compensation, compensation for resource exploitation can use some ways, such as monetary compensation, real compensation, employment compensation, quality of life compensation and so on.

\section{CONCLUSION}

The social resource exhausted city sustainable development and harmonious society is the ultimate goal of mine mining area of social policy construction. In the western sociological theory, the meaning of social harmony is similar to the "social integration". Thinking of social integration, it is most intensively and directly reflected in the social solidarity theory of Durkheim, who is one of the founders of classical sociological theory, and the social equilibrium theory of Parsons, who is in the classical theory of the great. Its argument established a strong foundation for social integration and provided important thinking foundations for building harmonious society. Marx and Dahrendorf's social conflict theory has the same theory direction and the different function of theory to China's the construction of harmonious society. In other words, both explain the phenomenon of modern society in the way of conflict and to look at the events of modern society from the perspective of conflict. To construct an harmonious society, we should pay attention to social conflict, which is caused by unequal distribution of right and interest. And it should be based on a platform, where the cognition and resolution of social conflict are able to meet; be confined in an extent, where restriction of conflict lead the development of society.
The harmonious society is concerned with how to integrate contradictory social conflict and how to achieve social integration after social differentiation. It's basic thinking of the construction of harmonious mining area that Interests integration, institutional integration and community Integration Social policy is the key to the realization of social integration. From foreign mining area of social welfare policy, combined with our country and local government related policy documents and explore the social policy model suitable for the villagers and village collective mining area's damage compensation, land compensation, employment compensation, survival and life quality compensation and so on.

\section{REFERENCES}

[1] http://baike.baidu.com/link?url=IPH2bZqg2Dh8Mf5YCMvKt6hhASVK aeWojBd494J2Pu474Q9VPu08OUyKkNA0MdmBMnt7cIq5R_URQO KM3e4X7

[2] Ulrich Beck. Risk society[M].He Bowen Translation, Yilin press.2004.

[3] Jia Ding.The vicissitudes of Dongchuan bronze[M].Science Press.2009.

[4] Charles Wright Mills. Power elite[M].Xu Rong Translation, Nanjing University press, 2004.

[5] Lewis Coser. The function of social conflict[M]. Sun Liping Translation. Huaxia Publishing Press.1989.

[6] Saunders.Community theory[M]. Xu Zhen Translation, Liming Culture enterprise, 1982.

[7] Sun Liping. Transformation andFracture: The Changes of Chinese social structure since the reform[M].Tsinghua University press, 2004

[8] Li Peilin, Social Conflict and Class Consciousness[M], Social Science Literature Publishing House, 2005.

[9] Li Hanlin. Structural tension in the process of social change[M]. Chinese social science, 2010(02). 